\title{
INTRODUCTION
}

\section{The History of Educational Finance}

\author{
Anne Berg \\ Samuel Edquist \\ Christin Mays \\ Johannes Westberg \\ Andreas Åkerlund
}

The study of the economics of education has a history that can be regarded as long, or short, depending on the perspective. As early as the eighteenth and nineteenth century, physiocrats and classical economists dealt with education as an economic phenomenon. ${ }^{1}$ However, it was first in the middle of the twentieth century that education became a fundamental issue in the science of economics, due in large part to human capital theory which, among many other things, highlighted the impact of educational attainment on economic growth. ${ }^{2}$

One of the key areas of research within the field of education economics is the study of educational finance. In the OECD countries, the expected length of five-year old child's education in the year 2000 was 16.8 years, representing more than onefifth of a child's life expectancy. In addition, an increasing number of these individuals are internationally mobile during their education. The funding of this lengthy and geographically diverse education entails enormous costs. In 2004, it was reported that the OECD countries spent an average of 5.8 percent of their GDP on education alone. ${ }^{3}$

Issues regarding the funding of such immense costs have generated research on topics such as the effects of the marketisation of education, and the balance between national, regional and local funding of education. ${ }^{4}$ Some of this research is, as will be discussed below, historical in nature. The articles in this special issue discuss the

1 B. F. Kiker, "The Historical Roots of the Concept of Human Capital," The Journal of Political Economy 74, no. 5 (1966), 481-99; David Mitch, "The Economic History of Education," in Routledge Handbook of Modern Economic History, ed. Robert Whaples and Randall E. Parker (New York: Routledge, 2013), 247.

2 Erik Mellander, "Utbildningsekonomi," in Individ, samhälle, lärande: Åtta exempel på utbildningsvetenskaplig forskning, ed. Ulf P. Lundgren (Stockholm: Vetenskapsrådet, 2008), 86; Gareth Williams, "The Economics of Education: Current Debates and Prospects," British Journal of Educational Studies 30, no. 1 (1982), 97-107.

3 David Mitch, "School Finance," in International Handbook on the Economics of Education, ed. Geraint Johnes and Jill Johnes (Cheltenham: Edward Elgar, 2004), 262-63; OECD, Education at a Glance: OECD Indicators (Paris: OECD, 2007), 205.

4 H. M. Levin, "School Finance," in Economics of Education: Research and Studies, ed. George Psacharopoulous (Oxford: Pergamon, 1987), 426; Allan Odden and Larry Picus, School Finance: a Policy Perspective (New York: McGraw-Hill, 1992), xv-xvii; Mitch (2004), 262-64. 
history of educational finance, using three particular sectors as points of departure: primary education, popular education (folkbildning) and higher education. Below, these articles are placed into their respective fields of research.

\section{The history of schooling and school finance}

The ever-growing research into the history of schooling has dealt with a wide variety of topics. Apart from school policy and administration, and the history of curriculum and individual school subjects, the research field has covered topics such as the history of schoolhouses, school yards, teachers and pupils. The number of theoretical perspectives has multiplied. In addition to basic concepts such as gender, social class and ethnicity, the research also utilises concepts such as social discipline, professionalisation, discourse, lived experience, material culture, and more. ${ }^{5}$

Consequently, our knowledge of the history of schooling has increased immensely. Just in the last couple of years, studies in the Nordic countries have, for example, dealt with the history of urban schools in Norway during the eighteenth century, the introduction of state school inspectors in Sweden during the nineteenth century, and school architecture in Denmark during the twentieth century. ${ }^{6}$ In addition, there are studies that have dealt with the coping strategies of rural teachers in Finland, and the demographics of Icelandic schoolteachers. ${ }^{7}$

The expanding research on the history of schooling has, however, traditionally paid little attention to matters of school finance. The history of primary school finance deals, in its most general definition, with issues such as how the financial burdens of the school system are shared between the public and the private sector, between levels of local and central government, and how the school systems' resources are created, distributed among schools and school districts, and spent on teachers' salaries, administration and premises. ${ }^{8}$ The history of school finance therefore covers a wide area, ranging from issues on school policy and school administration, to the implementation of school finance reform and regional patterns of revenues and expenditures.

5 See e.g., Bengt Sandin, Hemmet, gatan, fabriken eller skolan: Folkundervisning och barnuppfostran i svenska städer 1600-1850 (Lund: Arkiv, 1986); Christina Florin, "Social Closure as a Professional Strategy: Male and Female Teachers from Co-Operation to Conflict in Sweden, 1860-1906," History of Education 20, no. 1 (1991); Loftur Guttormsson, "Island: Læsefærdighed og folkeuddannelse 1540-1800," in Ur nordisk kulturhistoria: Läskunnighet och folkbildning före folkskoleväsendet. XVIII nordiska historikermötet, Jyväskylä, ed. Mauno Jokipii and Ilkka Nummela (Jyväskylä Yliopisto, 1981); Ning De Coninck-Smith, Barndom og arkitektur: Rum til danske børn igennem 300 år (Aarhus: Klim, 2011); Anna Larsson, "A Children's Place? The School Playground Debate in Postwar Sweden," History of Education 42, no. 1 (2013).

6 Ning de Coninck-Smith, "Danish and British Architects at Work: A Micro-Study of Architectural Encounters after the Second World War," History of Education 39, no. 6 (2010); Ida Bull, "Industriousness and Development of the School-System in the Eighteenth Century: The Experience of Norwegian cities," History of Education 40, no. 4 (2011); Jakob Evertsson, "Folkskoleinspektionen och moderniseringen av folkskolan i Sverige 1860-1910," Historisk tidskrift 132, no. 4 (2012).

7 Erkko Anttila and Ari Väänänen, "Rural Schoolteachers and the Pressures of Community Life: Local and Cosmopolitan Coping Strategies in Mid-Twentieth-Century Finland," History of Education 42, no. 2 (2013); Ólöf Garðarsdóttir, "Teaching on the Eve of Public Schooling: Demographic and Social Features of Icelandic Schoolteachers in the Beginning of the 20th Century," in Education, State and Citizenship, ed. Mette Buchardt, Pirjo Markkola and Heli Valtonen (Helsinki: NordWel, 2013).

8 Compare with definitions of school finance in Levin (1987), 426-27; Odden and Picus (1992), 1; Mitch (2004), 260-64. 
Despite the relative lack of interest in how the funding of schooling was historically structured, a number of fundamental investigations have been carried out. These include Carl Kaestle's analysis of school funding in Massachusetts during the nineteenth century, Norman Morris' investigation into the politics of school finance reforms in England and Wales in 1833-1870, and Raymond Grew and Patrick Harrigan's detailed studies of school financing in France during the nineteenth century. ${ }^{9}$ In addition, David Mitch's analysis of the relationship between government grants and schooling in England must be recognised, along with Peter Lindert's and Nancy Beadie's publications, which, among other things, have dealt with the issue of decentralised school funding. ${ }^{10}$

These studies highlight a number of topics to be dealt with in future studies. Morris demonstrates an interest in issues of policy, which have often been at the centre of school funding reforms, while the studies of Mitch and Grew \& Harrigan represent studies into the relation between schooling, government interventions and society. Lindert's study raises questions regarding the international history of school finance, and the patterns which emerge at that level of analysis, while Beadie's work is an example of the fruitfulness of local case studies.

However, it may be possible to recognise an increased interest in the history of school finance. At the World Economic History Conference of 2012, a session titled "Financing the Rise of Popular Schooling" was organised by Latika Chaudhary, and similar topics have been covered by sessions at the European Social Science and History Conference in 2012 and 2014, and the Annual Meeting of the Social Science History Association in 2014. Moreover, a number of studies on the subject have been published recently, in addition to the ones mentioned above. ${ }^{11}$

In the Nordic countries, however, comparatively little research has been conducted in respect to such matters. To our knowledge, the greatest efforts have been made on Swedish soil. Beside dissertations from the early twentieth century, which present some insights into the economic conditions of primary schools, Gunilla

9 Carl F. Kaestle and Maris A. Vinovskis, Education and Social Change in Nineteenth-Century Massachusetts (Cambridge: Cambridge University Press, 1980), ch. 7; Norman Morris, "Public Expenditure on Education in the 1860s," Oxford Review of Education 3, no. 1 (1977); Norman Morris, The Politics of English Elementary School Finance 1833-1870 (Lewiston: Edwin Mellen, 2003); Raymond Grew and Patrick J. Harrigan, School, State and Society: The Growth of Elementary Schooling in Nineteenth-Century France- a Quantitative Analysis (Ann Arbor: University of Michigan Press, 1991).

10 David Mitch, "The Impact of Subsidies to Elementary Schooling on Enrolment Rates in Nineteenth-Century England," The Economic History Review 39, no. 3 (1986); Peter Lindert, Growing Public: Social Spending and Economic Growth Since the Eighteenth Century Vol. 1 The Story (Cambridge: Cambridge University Press, 2004), ch. 5; Nancy Beadie, "Education, Social Capital and State Formation in Comparative Historical Perspective: Preliminary Investigations," Paedagogica Historica 46, no. 1-2 (2010).

11 See e.g., Latika Chaudhary, "Taxation and Educational Development: Evidence from British India," Explorations in Economic History 47, no. 3 (2010); Carla Aubry, "The 'Value of Schoooling': Rising Expenditures on Education in Winterthur, 1830-1850," in History of Schooling: Politics and Local Practice, ed. Carla Aubry and Johannes Westberg (Frankfurt am Main: Peter Lang, 2012); Ingrid Brühwiler, Finanzierung des Bildungswesens in der Helvetischen Republik: Vielfalt - Entwicklungen - Herausforderungen (Bad Heilbrunn: Julius Klinkhardt Verlag, 2014); Jean-Philippe Croteau, "Le financement des écoles publiques à Montréal et à Toronto (1841-1997): Un baromètre pour mesurer les rapports entre la majorité et la minorité," Historical Studies in Education / Revue d'histoire de l'éducation 24, no. 2 (2012); Gabriele Cappelli, "Escaping from a Human Capital Trap? Italy's Regions and the Move to Centralized Primary Schooling, 1861-1936," DEPS Working Paper Series, Department of Economics and Statistics, University of Siena no. 688 (2013). 
Klose's licentiate thesis, completed in 1992 and published in 2011, constitutes a pioneering work, and so far the single most important contribution to this field of research. ${ }^{12}$ Using questionnaires that were distributed among Swedish parishes in 1768-1839, Klose deals with a number of significant questions regarding the funding of the Swedish school system before the first elementary school act of 1842 (1842 års folkskolestadga). In short: what costs characterised this school system, who covered them, and why?

Using such questions as point of departure, Klose maps the emergence of a rudimentary school system which was placed primarily in the diocese of Lund, in southernmost Sweden. ${ }^{13}$ As in other studies on the expansion of mass education, peasants appear to have been the driving force. ${ }^{14}$ Although there were instances when landlords participated in the funding of, for example, school houses, it was the parishioners that covered most of the costs associated with schooling.

Over the past few years, it is possible to discern a growing interest in the history of school finance, primarily at the Department of Education at Uppsala University. In this research milieu, a number of aspects of the expanding mass education in 1820-1950 have been studied by historians and sociologists of education. Esbjörn Larsson has dealt with the economic conditions and consequences of monitorial education during the early nineteenth century. Johannes Westberg has engaged with the funding of the expanding mass education in 1840-1900, Madeleine Michaëlsson has analysed the different ways private iron mills contributed to the public primary school system 1850-1920 and Magnus Svensson has analysed the centralising tendencies of the school system in the early twentieth century. ${ }^{15}$

More than simply answering questions, these studies also raise a number of questions regarding the funding of school systems at central and local levels, and the local and regional differences in school funding. Challenging issues regarding the implications of various funding systems for the educational activities of schools are also among the questions that require further study, which also holds true for the changing role of the market in education.

12 Gunilla Klose, Folkundervisningens finansiering före 1842 (Uppsala: SEC, Uppsala universitet, 2011). For older dissertations on the subject, see Karl Linge, Stockholms folkskolors organisation och förvaltning åren 1842-1861: Studier i den svenska folkskolans historia (Stockholm: Stockholms högskola, 1914), 140-50; Johan Wallner, Folkskolans organisation och förvaltning $i$ Sverige under perioden 1842-1861 (Lund: Lunds universitet, 1938), ch. XI.

13 Regarding the system of home instruction, see Egil Johansson, "The History of Literacy in Sweden," in Understanding Literacy in its Historical Contexts: Socio-Cultural History and the Legacy of Egil Johansson, ed. Harvey J. Graff, Alison Mackinnon, Bengt Sandin and Ian Winchester (Lund: Nordic Academic Press, 2009).

14 See e.g., Ben Eklof, “The Myth of the Zemstvo School: The Sources of the Expansion of Rural Education in Imperial Russia: 1864-1914," History of Education Quarterly 24, no. 4 (1984).

15 For publications stemming from these projects, see e.g., Esbjörn Larsson, En lycklig Mechanism: Olika aspekter av växelundervisningens som en del av 1800-talets utbildningsrevolution (Uppsala: Historiska institutionen, 2014); Madeleine Michaëlsson, "From Tree Felling to Silver Lining: Diverse Ways of Funding Elementary Schools among Swedish Ironworking Communities, 1830-1930," in History of Schooling: Politics and Local Practice, ed. Carla Aubry and Johannes Westberg (Frankfurt am Main: Peter Lang, 2012); Johannes Westberg, "Stimulus or Impediment? The Impact of Matching Grants on the Funding of Elementary Schools in Sweden during the Nineteenth Century," History of Education 41, no. 1 (2013); Johannes Westberg, Att bygga ett skolväsende: Folkskolans förutsättningar och framväxt 1840-1900 (Lund: Nordic Academic Press, 2014). 


\section{The funding of popular education}

In Sweden and the other Nordic countries, popular education has become an established field of research in recent decades. Since the phenomena we discuss have no commonly accepted term, and the terms used have different meanings in different national and linguistic settings, our terminology must be explained.

In the Swedish language, the term generally used in public as well as scholarly discourse is folkbildning. Similar terms are also used in Norwegian and Danish (folkeopplysning, folkeoplysning), and in earlier epochs in Finnish (kansansivistys). Today, the common Finnish term is (vapaa) sivistystyö - (free) educational work. In all of these cases, the concepts cover a relatively wide field of non-formal educational institutions; on the one hand: folk high schools, and on the other: study circles, public lectures and various cultural activities, often organised by larger study organisations. ${ }^{16}$ Thus, Nordic popular education has a much wider meaning in comparison to other countries, where the concept is often associated with radical and emancipatory education from below, usually connected to labour movements aiming at social and political change. ${ }^{17}$ This form of popular education also exists in the Nordic countries, but only as a segment of a larger mass of educational activities, prompted by different political and social forces.

To add to this confusion, activities labelled as popular education have also been used for various types of education directed at the working classes, for example, regular schools. ${ }^{18}$ Although the term popular education poses problems, we have chosen to use it, as it is the most commonly accepted term in academia, rather than alternative terms such as non-formal adult education. ${ }^{19}$

Nordic popular education must also be perceived as a discursively shaped phenomenon whose organisational forms have shifted over time. For instance, public libraries, founded in the second half of the nineteenth century and onwards, were for a long time considered central parts of popular education by social movements and governmental officials. However, today they are only partially addressed as such. The reason for this change is due to the fact that modern libraries, in nearly every case, are run by municipal authorities.

Popular education has traditionally been connected to the voluntary, nonprofit, third sector in public discourse. This highly ideological view of the phenomenon deeming it as independent from the state, free and voluntary - has deeply affected

16 For a brief summary of existing institutions in the Nordic countries, see Folkbildning och vuxenundervisning i Norden: Struktur - omfäng - ekonomi: En jämförande kartläggning av offentliga resurser till folkbildning och vuxenundervisning i de nordiska länderna (København: Nordiska ministerrådet, 1997), 21-39.

17 Jim Crowther, "Reflections on popular education in the UK and Sweden," in Popular Education, Power and Democracy: Swedish Experiences and Contributions, ed. Ann-Marie Laginder, Henrik Nordvall, and Jim Crowther (Leicester: Niace, 2013).

18 Sjaak Braster, Frank Simon, and Ian Grosvenor, eds., A History of Popular Education: Educating the People of the World (London: Routledge, 2013).

19 Non-formal adult education can be well defended as a more precise concept for scholarly purposes. Even that has its problems, though. First, popular education organisations generally also include youths from the age of 14-15 years. Secondly, the term "non-formal" - making boundaries towards regular schools, universities and adult education that is directly aimed at complementing regular schools - is also difficult. For example, folk high schools can be considered partially formal, e.g. in Sweden having a sort of grades, often functioning as an alternative to formal adult education, and in some cases serving as outright vocational education. 
its historiography. One can probably find at least a partial explanation in the fact that the history of popular education for a long time was conducted by researchers close to the field of application. Consequently, popular education has generally been studied from an internal perspective, not as a part of a larger context of cultural and/ or educational institutions. Some scholars have described existing research as protective of the strict borders between popular education and institutions not considered part of the idealised vision of it. For example, vocational education in folk high schools, has only recently been investigated by scholars. ${ }^{20}$

Popular education has largely been studied in a context of ideology, culture and pedagogy. Particularly, the educational doctrines in organisations and certain influential individuals have been at the centre of inquiry. ${ }^{21}$ However, the financial contexts and material preconditions of popular education have largely been overlooked, even though most institutions have depended on state and municipal funding. Perhaps this blind spot is a result of the aforementioned ideological and idealised view of the subject. Even if quite a few historiographers have acknowledged government grants, they have only briefly addressed their design, impact, and regulatory functions. ${ }^{22}$ Remarkably, considering the rather vast literature on popular education in the Nordic countries, only a few have made the economics of popular education the main topic of analysis. ${ }^{23}$ In adjacent fields, such as the sectors of social movements or formal adult education, financial issues and material conditions have held a more pronounced position. ${ }^{24}$

Analyses on the economic contexts of popular education must be linked to even wider fields, such as cultural politics, and general questions concerning the relationship between the state and the field often termed civil society. For example, this

20 Anna Lundin, Folkbildningsforskning som fält - från framväxt till konsolidering (Linköping: Linköpings universitet, 2008); Fay Lundh Nilsson and Anders Nilsson, eds., Två sidor av samma mynt? Folkbildning och yrkesutbildning vid de nordiska folkhögskolorna (Lund: Nordic Academic Press, 2010).

21 E.g., Erica Simon, Réveil national et culture populaire en Scandinavie: La genèse de la højskole nordique 1844-1878 (Copenhagen \& Stockholm: Scandinavian University Books, 1960); Lars Arvidson, Folkbildning och självuppfostran: En analys av Oscar Olssons idéer och bildningssyn (Stockholm: Tiden, 1991); Bernt Gustavsson, Bildningens väg: Tre bildningsideal i svensk arbetarrörelse 1880-1930 (Stockholm: Wahlström \& Widstrand, 1991); Per Sundgren, Kulturen och arbetarrörelsen: Kulturpolitiska strävanden från August Palm till Tage Erlander (Stockholm: Carlsson, 2007); Sirkka Ahonen and Jukka Rantala, eds., Nordic Lights: Education for Nation and Civic Society in the Nordic Countries, 1850-2000 (Helsinki: Finnish Literature Society, 2001); Ove Korsgaard, Kampen om folket: Et dannelsesperspektiv på dansk historie gennem 500 år (København: Gyldendal, 2004); Sigvart Tøsse, Folkbildning som universellt fenomen: Om betydelser och motsvarigheter $i$ historiskt och internationellt perspektiv (Linköping: Linköpings universitet, 2009).

22 E,g, Sven Swensson, "Folkhögskolan och myndigheterna," in Svensk folkhögskola 100 år, vol. 1 (Stockholm: Liber, 1968); Bo Andersson, Folkbildning i perspektiv: Studieförbunden 1870-2000: Organisering, etablering och profilering (Stockholm: LTs förlag, 1980), 256-70; Lena Lindgren, Kan en filthatt stärka demokratin? Om mål och ideal i folkbildningssammanhang (Stockholm: Carlsson, 1996), 31-40; Sigvart Tøsse, Folkeopplysning og vaksenopploring: Idear og framvekst gjennom 200 år (Oslo: Didakta Norsk Forlag, 2005), 88.

23 Exceptions so far concern the last decades, when popular education has had to compete on an educational market, e.g., Ann-Louise Petersen, Marknadsorientering inom folkbildningen: Fritt och frivilligt $i$ ett nytt ljus (Göteborg: Bokförlaget BAS, 2006). There are also governmental reports concerning the field, e.g., the above cited Folkbildning och vuxenundervisning $i$ Norden (1997).

24 Olof F. Lundquist, Studiestöd för vuxna: Utveckling, utnyttjande, utfall (Göteborg: Göteborgs universitet, 1989); Pernilla Jonsson and Silke Neunsinger, Gendered Money: Financial Organization in Women's Movements, 1880-1933 (New York: Berghahn Books, 2012). 
larger context has influenced research on nineteenth century philanthropic associations and their funding. ${ }^{25}$ Answering questions on how different forms of government control, including economic funding, effected the voluntary sector's relative autonomy, producing bureaucratic structures within organisations etc., are also highly relevant, ${ }^{26}$ as are previous analyses on the funding of the cultural sector. ${ }^{27}$

\section{International mobility in higher education and research}

In higher education, research financing, teaching costs and salaries are constant themes. This is even truer for the internationalisation of higher education. Exchange programs, scholarly visits and guest lectures, international teaching and research collaborations are costly undertakings which demand funding for individuals as well as for participating institutions. Historically, there has been a strong consensus that science is international and therefore international collaborations and experiences are important for the national context. Common arguments are that travelling and collaborating promotes scientific advancement, international understanding, national growth and development as well as develops the learning processes of students and researchers alike.

There are, however, various ways to approach the subject of internationalisation and economy. Different aspects of this complex problem have been dominant in international research in different time periods. This variation in foci does not imply that other aspects have ceased to be important, but rather that certain aspects either have been seen as obsolete or taken for granted by research(ers).

For the last two decades, a dominant rationale has been competition on an international educational market. ${ }^{28}$ Especially in countries receiving a large number of international students - foremost the USA, Great Britain and Australia - recruiting students from abroad has been seen as a way for universities to compensate for funding deficits and for states to gain additional revenue. Higher education is increasingly becoming an important export product for various countries through the establishment of international branch campuses, while traditional international students contribute to the economies of the countries in which they reside. For example, estimates state that foreign students contributed $\$ 18.8$ billion to the US economy in the academic year 2009/10 alone. ${ }^{29}$ Thus, presently, higher education is

25 Alan J. Kidd, State, Society and the Poor in Nineteenth-Century England (Basingstoke: Macmillan, 1999).

26 Stefan Toepler, "Government Funding Policies," in Handbook of Research on Nonprofit Economics and Management, ed. Bruce A. Seaman and Dennis R. Young (Cheltenham: Edward Elgar, 2010); Tommy Lundström and Fredrik Wijkström, "Sweden," in Defining the Nonprofit Sector: A Cross-National Analysis, ed. Lester M. Salamon and Helmut K. Anheier (Manchester: Manchester University Press, 1997); Erik Amnå, Jourhavande medborgare: Samhällsengagemang i en folkrörelsestat (Lund: Studentlitteratur, 2008), 137-46 and 158-62; Bo Rothstein, Den korporativa staten: Intresseorganisationer och statsförvaltning i svensk politik (Stockholm: Norstedts juridik, 1992).

27 Annette Zimmer and Stefan Toepler, "The Subsidized Muse: Government and the Arts in Western Europe and the United States," Journal of Cultural Economics 23, no. 1-2 (1999), 39-46. For a Swedish study on cultural politics which describes the impact of public funding on a general level, see Sven Nilsson, Kulturens nya vägar: Kultur, kulturpolitik och kulturutveckling i Sverige (Malmö: Polyvalent, 2003).

28 Nigel M. Healey, “Is Higher Education Really 'Internationalising'?” Higher Education 55, no. 3 (2008).

29 Laura E. Rumbley, Philip G. Altbach and Liz Reisberg, "Internationalization Within the Higher Education Context," in The SAGE Handbook of International Higher Education, ed. Darla K. Deardoff et al. (London: SAGE, 2012), 22. 
seen as a commodity which can be traded freely on a global educational market to whoever is willing to pay for it. ${ }^{30}$

There are winners and losers in any market. In the international market of education the winners are most obviously larger countries with highly ranked universities in majority English speaking countries. The losers are to a large extent the poorer countries of the globe with weak systems of higher education which are drained of economic resources (through students paying tuition fees abroad) and of skilled academic labour (through the international recruitment of researchers). To a lesser extent the losers are also smaller states in the industrialised world, who are not able to compete with larger states in the recruitment of international students and who themselves tend to be drained of their academic youth.

This idea of a global market has very recently also found its advocates within the Swedish government. In Sweden, foreigners previously had the same access to higher education as nationals which, in combination with a large amount of courses and programs in English, made the country attractive to foreign students. The introduction of tuition fees for free movers from countries outside the EU in 2009, however, caused a drop of 73 per cent in the foreign applications to Swedish master programs for the academic year $2010 / 11 .{ }^{31}$ It is obvious that the country lost much of its competitive advantage once tuition fees became mandatory for non-EU students in Sweden. The global market is anything but easy for a small country like Sweden, as Philip G. Altbach argued in 2002:

Open Markets, at least in higher education, reinforce the inequalities that already exist. If educational borders are completely open, the strongest and wealthiest education providers will have unlimited access. Countries and institutions that cannot compete will find it difficult to flourish. This means that developing countries and smaller industrialized nations will be at considerable disadvantage. ${ }^{32}$

Competition on an international market is brutal, but the most interesting question is from where this global hierarchy originates. Why are some countries more attractive than others? The answer to this question is multi-layered. Part of it lies in the use of English as a lingua franca for higher education and research, which benefits certain universities and regions. ${ }^{33}$ In fact the British Council projected that in 2020, there will be 5.8 million places for international students in the world, and 45 percent of these places will be in English-speaking countries. ${ }^{34}$ The present hierarchy also has a geographical dimension in which students and researchers mainly travel from the global South to the global North. International educational exchange must

30 Philip G. Altbach, "Knowledge and Education as International Commodities: The Collapse of the Common Good," International Higher Education 28 (2002).

31 Immigration of International Students to Sweden, European Migration Network, report no. 2012:1 (Norrköping: Swedish Migration Board, 2012), 45.

32 Altbach (2002), 3.

33 Philip G. Altbach, "Globalization and the University: Realities in an Unequal World," in International Handbook of Higher Education, ed. Philip G. Altbach and James J.F. Forest (Dordrecht: Springer, 2007), 126-28; Ryuko Kubota, "Internationalization of Universities: Paradoxes and Responsibilities," The Modern Language Journal 93, no. 4 (2009).

34 Veronica Lasanowski, "Can Speak, Will Travel: The Influence of Language on Global Student Mobility," in International Students and Global Mobility in Higher Education, ed. Rajika Bhandari and Peggy Blumenthal (New York: Palgrave Macmillan, 2011), 195. 
therefore be seen from the brain drain perspective; the highly educated in poorer countries tend to migrate to the richer part of the globe. ${ }^{35}$

This north-south brain drain is not new to the post-Cold War world although the commodification of education and the neo-liberal faith in markets to organise society has given this problem a new dimension. The brain drain discussion began during the Cold War within the context of international aid and support to education systems in lesser developed countries. ${ }^{36}$ The idea of brain drain also neatly illustrates the ambiguity of international exchange. Within foreign aid projects, knowledge transfer from the industrialised to the industrialising world has always been an important dimension - in addition to material and economic aid. Educating select persons from industrialising countries would guarantee that instructions on the correct operation of machinery or the latest knowledge regarding agriculture or forestry reached skilled workers. It would also establish familiarity with "Western" values, such as representative democracy or equality, as well as create sympathy for capitalism and the market economy. It is therefore possible to claim that international academic exchange has contributed to the modernisation and marketisation of the globe. But it is also obvious that this idea had, and still has, various problems. Needless to say, many people educated in industrialised countries as a part of foreign aid programs never returned to their home countries to diffuse their knowledge, but choose to stay in or move on to a context where they could earn a better living with the acquired skills.

Hierarchies are not natural occurrences but, rather, result from historical processes. At the beginning of the unequal educational exchange of today lies in eighteenth century European colonialism and nineteenth century international imperialism. But it is not necessary to travel this far back in history to find another rationale at work than the present idea of the market. The Cold War was a completely different political-economic context for academic exchange. Here the international competition did not exist between universities or nation-states, but between superpowers, between capitalism in the West and communism in the East.

The Cold War also saw other types of international academic exchanges than those taking place within the stipulation of foreign aid. From a foreign policy perspective, exchange was seen as a way to normalise the relations between the East and the West, between NATO and the Warsaw pact. With the signing of the Lacy-Zarubin agreement between the United States and the Soviet Union in 1958, exchanges between the two superpowers began. Especially the Soviet Union pushed for international exchange in the sciences as a way to keep up with the technological advancements of the Western powers. ${ }^{37}$ Exchange was also an important part of the post-World War II reconciliation between Germany and France and German-US

35 Anthony Welch, "Myths and Modes of Mobility: The Changing Face of Academic Mobility in the Global Era," in Students, Staff and Academic Mobility in Higher Education, ed. Mike Byram and Fred Dervin (Newcastle: Cambridge Scholars, 2008), 298-99.

36 D. M. Windham, "International Financing of Education," in International Encyclopedia of Economics of Education, ed. Martin Carnoy (Oxford: Pergamon, 1995); Mun C. Tsang, "The Economics and Resourcing of Education," in Routledge International Companion to Education, ed. Bob Moon, Miriam Ben-Peretz and Sally A. Brown (London: Routledge, 2000), 149.

37 Nigel Gould-Davies, “The Logic of Soviet Cultural Diplomacy," Diplomatic History 27, no. 2 (2003), 206-08. 
exchange was a key feature within the democratisation of West Germany. ${ }^{38}$ The entire Fulbright program should be understood as a contribution to the Westernisation and democratisation of Europe. From an economic history perspective, these large state investments in academic exchange were not made in order to create revenue or to strengthen their own country's position on an international educational market. The main aim instead was, apart from the more obvious motive of knowledge transfer, to create contacts and sympathies between countries and as an integral part of the Cold War value conflict between capitalism and communism.

Before World War II, international academic exchange had yet another rationale, one where the state was less visible. During the interwar years as well as in the decades preceding World War I, exchange was to a much larger extent paid for by private or semi-state actors such as professional organisations, university-administrated funds or philanthropic foundations. In particular, the "Big 3 " foundations in the United States, Carnegie, Rockefeller, and Ford, but also actors such as the Alexander von Humboldt-Stiftung in Germany played a crucial part in enabling international scholarly mobility and exchange. ${ }^{39}$ This system, which began to grow in the interwar period, funded academics who could otherwise not afford to travel abroad. ${ }^{40}$ In his research on Uppsala University Jan Sundin concludes that the increasing amount of scholarships for foreigners through the Swedish state and the University student union laid the foundations for the increase of foreign scholars in the 1930s and after World War II. ${ }^{41}$ This interest for international cultural cooperation, which Akira Iriye has called cultural internationalism, shares its origins with this philanthropic approach to exchange, which was later championed by state actors after World War II. ${ }^{42}$

Hand in hand with philanthropy is the idea of modernisation through exchange. The development of the domestic industries and medicinal expertise are often mentioned as motives for scholarly travels. ${ }^{43}$ The change of terminology from exchange to travel is motivated here, because of the phenomenon's unregulated character. What has gained some attention in the Swedish case is the remigration of Swedish engineers from North America, who upon return used the skills they gained abroad within Swedish industry, thus placing this academic mobility within the great trans-Atlantic migration of the nineteenth century. ${ }^{44}$ One cannot talk of exchange programs or fixed bilateral agreements in this period, but more of scholars travelling

38 Karl-Heinz Füssl, "Between Elitism and Educational Reform: German-American Exchange Programs, 1945-1970," in The United States and Germany in the Era of the Cold War, 1945-1990: A Handbook, ed. Detlef Junker (West Nyack, NY: Cambridge University Press, 2004).

39 Volkhard Laitenberger, Akademischer Austausch Und Auswärtige Kulturpolitik: Der Deutsche Akademische Austauschdienst (DAAD) 1923-1945 (Göttingen: Musterschmidt, 1976).

40 Earl F. Cheit and Theodore E. Lobman, Foundations and Higher Education: Grant Making from the Golden Years through Steady State (Berkeley: Carnegie Council for Policy Studies, 1980), 2-4.

41 Jan Sundin, Främmande studenter vid Uppsala universitet före andra världskriget: En studie i studentmigration (Uppsala: Uppsala universitet, 1973), 156-57; 177.

42 Akira Iriye, Global Community: The Role of International Organizations in the Making of the Contemporary World (Berkeley: University of California, 2012), 45.

43 Henrik Brissman, Mellan nation och omvärld: Debatt i Sverige om vetenskapens organisering och finansiering samt dess internationella och nationella aspekter under 1900-talets första hälft (Lund: Lunds universitet, 2010), 273-75.

44 Per-Olof Grönberg, Learning and Returning: Return Migration of Swedish Engineers from the United States, 1880-1940 (Umeå: Umeå University, 2003). 
abroad for the purpose of study, research or learning from colleagues at foreign universities or research facilities. Returning to the present situation, this is still the main purpose of these travels, but this same movement of persons now takes place in a completely different political and economic context.

It cannot be stressed enough that the process which has been described in reverse chronology here is of a cumulative rather than a periodic character. This means that the actors and rationales present at an earlier stage in history do not cease to exist as new rationales or different actors appear on the field of international exchange. Using the present day rationale of marketisation and commodification, the old state-sponsored programs of the Cold War continue to function alongside with the work of professional associations and philanthropic foundations with their roots in the first half of the twentieth century. What seems to be the case is that earlier programs or institutions are given new roles and functions every time the rationale changes. A common feature is the collaborative character of international exchange, especially between state and non-state actors, such as big foundations or international organisations, like UNESCO. Organisations can also change their aim and scope over time. One example is the philanthropic foundations in the United States from the early twentieth century which took an active part in establishing strong connections, if not to say an educational and scholarly dependence, between the United States and parts of the Third World during the Cold War. ${ }^{45}$

This last example inevitably draws attention to the funding of international mobility, a subject which thus far has lacked systematic scholarly attention, despite that the question of who funds mobility is highly relevant. Study abroad financed by students and their families is a major investment in education and the majority of these persons apply for a scholarship to finance their stays abroad. But obtaining a scholarship or similar financial support always includes a process of selection which draws the attention to the providers of such support. Why is support given, how and by whom? This is not only a question for the present as, historically, a great deal of scholarly and student movement was made possible through foundations, professional associations or state programs. As these different kinds of institutions were established in different historical periods, a historical study of their work contributes to an understanding of both the internal financial logic of such institutions as well as their impact on the general field of international exchange.

The existing literature on exchange and scholarly travel tends to only briefly address financing as, generally, the main interest normally lies elsewhere. The available literature on exchange as a part of foreign policy or public diplomacy, for instance, tends to focus on the political ideas behind or the implementation of exchange programs rather than on how they are financed. ${ }^{46}$ However, the impacts of such programs, such as the Fulbright program, are better researched. For instance,

45 Edward H. Berman, The Influence of the Carnegie, Ford and Rockefeller Foundations on American Foreign Policy: The Ideology of Philanthropy (Albany: SUNY Press, 1983).

46 See Liping Bu, "Educational Exchange and Cultural Diplomacy in the Cold War," Journal of American Studies 33, no. 3 (1999); Kevin V. Mulcahy, "Cultural Diplomacy and the Exchange Programs: 1938-1978," The Journal of Arts Management, Law, and Society 29, no. 1 (1999); Yale Richmond, Cultural Exchange of the Cold War: Raising the Iron Curtain (University Park, PA: Pennsylvania State University Press, 2003); Nancy Snow, "International Exchanges and the U.S. Image," The ANNALS of the American Academy of Political and Social Science 616, no. 1 (2008); Christopher Medalis, "The Strength of Soft Power: American Cultural Diplomacy and the Fulbright Program during the 1989-1991 Transition Period in Hungary," AUDEM: The International Journal of Higher Education and Democracy 3, no. 1 (2012). 
Jan C. Rupp has analysed the importance of the Fulbright program not only for the development of American studies in Holland but for Dutch-American exchange in general. ${ }^{47}$

Research on philanthropic foundations is broader, especially on the "Big 3" foundations in the United States: Carnegie, Ford and Rockefeller ${ }^{48}$ In the European context, there has been a growing interest in their international programs in Europe and the wider world after 1945, and the potential impact of these programs. ${ }^{49}$ In the Swedish context, there is less research on the "Big 3," though a recent dissertation has discussed the importance of the Rockefeller Foundation for the development of medical sciences at the Karolinska Institute..$^{50}$ The bulk of research is concentrated on two central actors within Swedish-US exchange, the Sweden-America Foundation and the American-Scandinavian Foundation. In particular, the research report by Andreas Melldahl presents an interesting statistical analysis of Sweden-America Foundation scholarship holders in relation to their subject areas and the perceived national needs formulated by foundation executives. ${ }^{51}$

There is still much research to be conducted regarding the financing of international scholarly exchange, especially in a historical perspective. There are especially two aspects which deserve more attention, one on the macro- and one on the micro-level. One is long-term investigations into the total investments in exchange by foundations, professional associations and state governments. How much has been invested, on what, with what intention and to what end? Answers to these questions would help us better understand the global flows of students and scholars over time and to unravel the historical economic base of today's exchange programs. The other is strongly related to these questions, but concerns the internal impacts of different forms of financing on the policies of the relevant actors. What impact do restrictions and regulations have on the grant and scholarship policies of these actors? To what extent are foundations bound to the restrictions placed by donors and state-funded

47 Jan C. Rupp, "The Fulbright Program, or the Surplus Value of Officially Organized Academic Exchange," Journal of Studies in International Education 3, no. 1 (1999).

48 Merle Curti, American Philanthropy Abroad: A History (New Brunswick, NJ: Rutgers, 1963); Ellen Condliffe Lagemann, The Politics of Knowledge: The Carnegie Corporation, Philanthropy, and Public Policy (Middletown, CT: Wesleyan University Press, 1989); Inderjeet Parmar, Foundations of the American Century: The Ford, Carnegie, and Rockefeller Foundations in the Rise of American Power (New York: Columbia University Press, 2012); Joseph C. Kiger, Philanthropists and Foundation Globalization (New Brunswick, NJ: Transaction Publishers, 2008).

49 Volker R. Berghahn, "Philanthropy and Diplomacy in the 'American Century", Diplomatic History 23, no. 3 (1999); Berman (1983); Oliver Schmidt, "Small Atlantic World. U.S. Philanthropy and the Expanding International Exchange of Scholars after 1945," in Culture and International History, ed. Jessica C. E. Gienow-Hecht and Frank Schumacher (New York: Berghahn, 2004); Volker R. Berghahn, America and the Intellectual Cold Wars in Europe (Princeton: Princeton University Press, 2001).

50 Olof Ljungström, Ämnessprängarna: Karolinska Institutet och Rockefeller Foundation 1930-1945 (Stockholm: Karolinska Institute University Press, 2010).

51 Erik J. Friis, The American-Scandinavian Foundation, 1910-1960 (New York: The American-Scandinavian Foundation, 1961); Dag Blanck, Sverige-Amerika Stiftelsen: De Första Sjuttio Åren 19191989 (Stockholm: Sverige-Amerika stiftelsen, 1989); Dag Blanck, "Scholars Across the Seas: The American-Scandinavian Foundation and the Sweden-America Foundation in the Trans-Atlantic Exchange of Knowledge," American Studies in Scandinavia 40, no. 1 (2008), 110-25; Andreas Melldahl, "Västerled tur och retur del 1: Utbildning och ekonomi. En ekonomhistorisk studie av Sverige-Amerika Stiftelsens stipendieverksamhet 1919-2006," SEC Research Reports, no. 44 (2008). 
agencies bound to the regulations of policymakers? This kind of micro-level study would not only help answer the broader questions asked above, but also show how scholarly exchange is impacted by economic matters.

\section{A special issue on educational finance}

The articles in this special issue contribute to the research fields outlined above in various ways. Johannes Westberg's article on teachers' allotted farms 1838-1900 deals with the fundamental question of how the expansion of mass schooling was funded. Previous research has shown that local governments such as municipalities, townships and school districts held the primary responsibility for funding the increasing numbers of schools and teachers during the nineteenth century. In his article, Westberg analyses the size and building stock of teachers' allotted farms in the Sundsvall region, and the work that they required from teachers and their households. Showing that the allotted farms could yield crops worth as much as a quarter of a teacher's salary, Westberg argues that allotted farms may have played a significant role in the funding of mass schooling in mid-nineteenth century. Since the number of allotted farms did not increase at the same rate as the number of schools and teachers, however, the significance of these farms diminished during the time period.

The field of popular education is the topic of Anne Berg's and Samuel Edquist's articles. Berg argues that the rise of a continuous popular educational sphere, during the period stretching from the 1870 s to the 1910s, partially can be explained by the implementation of a state grants system. By analysing the amount of state grants issued on a national scale, in combination with case-studies on the part played by public funding in a number of organisations that held lectures and folk high schools, it is shown that public funding played an important role. Public funding offered the organisations continuity and security as long as they followed the rules that the state required. Thus, in order to explain the rise of a continuous popular educational sphere, the state must be inserted into the overall picture side by side with known causes such as the formation of a working class and the rise of liberal-leftist political organisations.

Edquist argues that the state subsidies to Swedish institutions generally considered mediating popular education have largely shaped the very concept of popular education in the country. He shows that there is a historically developed tension between two parallel notions of popular education. On the one hand, there is a narrower ideal popular education-emphasising non-formality and independencethat has been discursively nurtured along with a broader organisational popular education, denoting the de facto institutions that have received public funding. Edquist puts forth that the organisational popular education is a reality in itself, spanning over border zones between, for example, non-formal and formal education.

The two articles on the financing of academic mobility are investigations into different funding forms through two distinct financing bodies. Together, these two articles draw attention to the fact that within the vast system of actors in international exchanges, there is more than one logic which determines the overall mobility of individuals.

Christin Mays and Andreas Åkerlund's article addresses the funding of international academic exchange between Scandinavia and the United States through the 
American-Scandinavian Foundation (ASF) in 1912-95. The article examines both the type and scope of various donations to the foundation and how these affected the scholarship operations in the periods before and after World War II. Mays and Åkerlund argue that philanthropic organisations - in this case, the American-Scandinavian Foundation - have a particular kind of internal economy as their operations are typically donor-funded. Therefore, under the investigated time period, it was the type, scope, and timing of donations which determined the scale and direction of scholarship operations through the ASF.

The article by Andreas Åkerlund on the mobility funding through the Swedish Institute (SI) is an investigation into a state-funded organisation for public diplomacy. It maps the funding sources of exchange through the SI from the founding in 1945 until 2010. One main result is that the SI exchange programs were funded by three distinct sources over the time period: the Ministry for Foreign Affairs, Official Development Assistance agencies and the Ministry of Education. It is clear that the various funding bodies directed their money to particular types of programs, thus creating different programs, which were gathered under the roof of the SI. The results indicate a need for further investigations into the funding of public diplomacy in order to create a more diverse understanding of the economic foundations of academic mobility.

Together, the articles of this special issue shed light upon the varying economic conditions of education. To be sure, this does not imply that we argue that the character of education may be reduced to, or solely explained by, economic factors. Instead, these articles have analysed how issues of funding always have consequences, regardless of the level of education or the period of time. Even though teachers' allotted farms, state subsidies and funding bodies such as the Ministry for Foreign Affairs at first sight may appear alien to what education is or should be, these articles illustrate how financing has had an impact in the most diverse of educational contexts.

As indicated above, this is a field of research that has thus far remained relatively neglected. While this special issue provides an introduction to current historical research regarding the funding of primary education, popular education and international mobility in higher education, it is also intended as a call for further research into these areas. As these articles demonstrate, there is much left to be discovered, if we broaden educational history beyond educational content, intentions and rhetoric. 


\section{References}

Ahonen, Sirkka, and Jukka Rantala, eds. Nordic Lights: Education for Nation and Civic Society in the Nordic Countries, 1850-2000. Helsinki: Finnish Literature Society, 2001.

Altbach, Philip G. "Globalization and the University: Realities in an Unequal World." In International Handbook of Higher Education, edited by Philip G. Altbach and James J.F. Forest, 121-39. Dordrecht: Springer, 2007.

Altbach, Philip G. "Knowledge and Education as International Commodities: The Collapse of the Common Good." International Higher Education 28 (2002), 2-5.

Amnå, Erik. Jourhavande medborgare: Samhällsengagemang $i$ en folkrörelsestat. Lund: Studentlitteratur, 2008.

Andersson, Bo. Folkbildning i perspektiv: studieförbunden 1870-2000 - organisering, etablering och profilering. Stockholm: LTs förlag, 1980.

Anttila, Erkko and Ari Väänänen. "Rural Schoolteachers and the Pressures of Community Life: Local and Cosmopolitan Coping Strategies in Mid-twentieth-Century Finland." History of Education 42, no. 2 (2013), 182-203.

Arvidson, Lars. Folkbildning och självuppfostran: En analys av Oscar Olssons idéer och bildningssyn. Stockholm: Tiden, 1991.

Aubry, Carla. "The 'Value of Schooling': Rising Expenditures on Education in Winterthur, 1830-1850." In History of Schooling: Politics and Local Practice, edited by Carla Aubry and Johannes Westberg, 90-106. Frankfurt am Main: Peter Lang, 2012.

Beadie, Nancy. "Education, Social Capital and State Formation in Comparative Historical Perspective: Preliminary Investigations." Paedagogica Historica 46, no. 1-2 (2010), 15-32.

Berghahn, Volker R. "Philanthropy and Diplomacy in the "American Century." Diplomatic History 23, no. 3 (1999), 393-419.

Berghahn, Volker R. America and the Intellectual Cold Wars in Europe. Princeton: Princeton University Press, 2001.

Berman, Edward H. The Influence of the Carnegie, Ford and Rockefeller Foundations on American Foreign Policy: The ideology of Philanthropy. Albany: SUNY press 1983.

Blanck, Dag. "Scholars across the Seas: The American-Scandinavian Foundation and the Sweden-America Foundation in the Trans-Atlantic Exchange of Knowledge." American Studies in Scandinavia 40, no. 1-2 (2008), 110-25.

Blanck, Dag. Sverige-Amerika Stiftelsen: De första sjuttio åren 1919-1989. Stockholm: Sweden-America Foundation, 1989.

Braster, Sjaak, Frank Simon, and Ian Grosvenor, eds. A History of Popular Education: Educating the People of the World. London: Routledge, 2013.

Brissman, Henrik. Mellan nation och omvärld: Debatt i Sverige om vetenskapens organisering och finansiering samt dess internationella och nationella aspekter under 1900-talets första hälft. Lund: Lunds universitet, 2010.

Brühwiler, Ingrid, Finanzierung des Bildungswesens in der Helvetischen Republik: Vielfalt - Entwicklungen - Herausforderungen. Bad Heilbrunn: Julius Klinkhardt Verlag, 2014.

Bu, Liping. "Educational Exchange and Cultural Diplomacy in the Cold War." Journal of American Studies 33, no. 3 (1999), 393-415. 
Bull, Ida. "Industriousness and Development of the School-system in the Eighteenth Century: The Experience of Norwegian cities." History of Education 40, no. 4 (2011), 425-46.

Cappelli, Gabriele. "Escaping from a Human Capital Trap? Italy's Regions and the Move to Centralized Primary Schooling, 1861-1936." DEPS Working Paper Series, Department of Economics and Statistics, University of Siena no. 688 (2013), $1-47$.

Chaudhary, Latika. "Taxation and Educational Development: Evidence from British India." Explorations in Economic History 47, no. 3 (2010), 279-93.

Cheit, Earl F. and Theodore E. Lobman. Foundations and Higher Education: Grant Making from the Golden Years through Steady State. Berkeley: Carnegie Council for Policy Studies, 1980.

Croteau, Jean-Philippe. "Le financement des écoles publiques à Montréal et à Toronto (1841-1997): Un baromètre pour mesurer les rapports entre la majorité et la minorité." Historical Studies in Education / Revue d'histoire de l'éducation 24, no. 2 (2012), 1-30.

Crowther, Jim. "Reflections on Popular Education in the UK and Sweden." In Popular Education, Power and Democracy: Swedish Experiences and Contributions, edited by Ann-Marie Laginder, Henrik Nordvall and Jim Crowther, 259-74. Leicester: Niace, 2013.

Curti, Merle. American Philanthropy Abroad: A History. New Brunswick, N.J, 1963.

de Coninck-Smith, Ning. "Danish and British Architects at Work: a Micro-study of Architectural Encounters after the Second World War." History of Education 39, no. 6 (2010), 713-30.

De Coninck-Smith, Ning. Barndom og arkitektur: Rum til danske børn igennem 300 år. Aarhus: Klim, 2011.

Eklof, Ben. "The Myth of the Zemstvo School: The Sources of the Expansion of Rural Education in Imperial Russia: 1864-1914." History of Education Quarterly 24, no. 4 (1984), 561-84.

Evertsson, Jakob. "Folkskoleinspektionen och moderniseringen av folkskolan i Sverige 1860-1910." Historisk tidskrift 132, no. 4 (2012), 624-51.

Florin, Christina. "Social Closure as a Professional Strategy: Male and Female Teachers from Co-operation to Conflict in Sweden, 1860-1906." History of Education 20, no. 1 (1991), 17-26.

Folkbildning och vuxenundervisning i Norden: Struktur - omfäng - ekonomi: En jämförande kartläggning av offentliga resurser till folkbildning och vuxenundervisning $i$ de nordiska länderna. København: Nordiska ministerrådet, 1997.

Friis, Erik J. The American-Scandinavian Foundation, 1910-1960. New York: The American-Scandinavian Foundation, 1961.

Füssl, Karl-Heinz. "Between Elitism and Educational Reform: German-American Exchange Programs, 1945-1970." In The United States and Germany in the Era of the Cold War, 1945-1990: A Handbook, edited by Detlef Junker, 409-16. West Nyack, NY: Cambridge University Press, 2004.

Garðarsdóttir, Ólöf. “Teaching on the Eve of Public Schooling: Demographic and Social Features of Icelandic Schoolteachers in the Beginning of the 20th Century." In Education, State and Citizenship, edited by Mette Buchardt, Pirjo Markkola and Heli Valtonen, 138-59. Helsinki: NordWel, 2013. 
Gould-Davies, Nigel. “The Logic of Soviet Cultural Diplomacy.” Diplomatic History 27, no. 2 (2003), 193-214.

Grew, Raymond and Patrick J. Harrigan. School, State and Society: The Growth of Elementary Schooling in Nineteenth-Century France- a Quantitative Analysis. Ann Arbor: University of Michigan Press, 1991.

Grönberg, Per-Olof. Learning and Returning: Return Migration of Swedish Engineers from the United States, 1880-1940. Umeå: Umeå University, 2003.

Gustavsson, Bernt. Bildningens väg: Tre bildningsideal i svensk arbetarrörelse 18801930. Stockholm: Wahlström \& Widstrand, 1991.

Guttormsson, Loftur. “Island: Læsefærdighed og folkeuddannelse 1540-1800.” In Ur nordisk kulturhistoria: Läskunnighet och folkbildning före folkskoleväsendet. XVIII nordiska historikermötet, Jyväskylä, edited by Mauno Jokipii and Ilkka Nummela, 123-91. Jyväskylä Yliopisto, 1981.

Healey, Nigel M. “Is Higher Education Really 'Internationalising'?” Higher Education 55 , no. 3 (2008), 333-55.

Immigration of International Students to Sweden, European Migration Network, report no. 2012:1. Norrköping: Swedish Migration Board, 2012.

Iriye, Akira. Global Community: The Role of International Organizations in the Making of the Contemporary World. Berkeley: University of California, 2012.

Johansson, Egil. "The History of Literacy in Sweden." In Understanding Literacy in its Historical Contexts: Socio-cultural History and the Legacy of Egil Johansson, edited by Harvey J. Graff, Alison Mackinnon, Bengt Sandin and Ian Winchester, 28-59. Lund: Nordic Academic Press, 2009.

Jonsson, Pernilla, and Silke Neunsinger. Gendered Money: Financial Organization in Women's Movements, 1880-1933. New York: Berghahn Books, 2012.

Kaestle, Carl F. and Maris A. Vinovskis. Education and Social Change in Nineteenth-Century Massachusetts. Cambridge: Cambridge University Press, 1980.

Kidd, Alan J. State, Society and the Poor in Nineteenth-Century England. Basingstoke: Macmillan, 1999.

Kiger, Joseph C. Philanthropists and Foundation Globalization. New Brunswick, NJ: Transaction Publishers, 2008.

Kiker, B. F. “The Historical Roots of the Concept of Human Capital." The Journal of Political Economy 74, no. 5 (1966), 481-99.

Klose, Gunilla. Folkundervisningens finansiering före 1842. Uppsala: SEC, Uppsala universitet, 2011.

Korsgaard, Ove. Kampen om folket: Et dannelsesperspektiv på dansk historie gennem 500 år. København: Gyldendal, 2004.

Kubota, Ryuko. "Internationalization of Universities: Paradoxes and Responsibilities." The Modern Language Journal 93, no. 4 (2009), 612-16.

Lagemann, Ellen Condliffe. The Politics of Knowledge: the Carnegie Corporation, Philanthropy, and Public Policy. Middletown, Conn: Wesleyan University Press, 1989.

Laitenberger, Volkhard. Akademischer Austausch und auswärtige Kulturpolitik: der Deutsche Akademische Austauschdienst (DAAD) 1923-1945. Göttingen: Musterschmidt, 1976.

Larsson, Anna. "A Children's Place? The School Playground Debate in Postwar Sweden." History of Education 42, no. 1 (2013), 115-30. 
Larsson, Esbjörn. En lycklig Mechanism: Olika aspekter av växelundervisningens som en del av 1800-talets utbildningsrevolution. Uppsala: Historiska institutionen, 2014.

Lasanowski, Veronica. "Can Speak, Will Travel: The Influence of Language on Global Student Mobility." In International Students and Global Mobility in Higher Education, edited by Rajika Bhandari and Peggy Blumenthal, 195. New York: Palgrave Macmillan, 2011.

Levin, H. M. "School Finance." In Economics of Education: Research and Studies, edited by George Psacharopoulous, 426-36. Oxford: Pergamon, 1987.

Lindert, Peter. Growing Public: Social Spending and Economic Growth Since the Eighteenth Century Vol. 1 The story. Cambridge: Cambridge University Press, 2004.

Lindgren, Lena. Kan en filthatt stärka demokratin? Om mål och ideal i folkbildningssammanhang. Stockholm: Carlsson, 1996.

Linge, Karl. Stockholms folkskolors organisation och förvaltning åren 1842-1861: Studier i den svenska folkskolans historia. Stockholm: Stockholms högskola, 1914.

Ljungström, Olof. Ämnessprängarna: Karolinska Institutet och Rockefeller Foundation 1930-1945. Stockholm: Karolinska Institute University Press, 2010.

Lundin, Anna. Folkbildningsforskning som fält - från framväxt till konsolidering. Linköping: Linköpings universitet, 2008.

Lundquist, Olof F. Studiestöd för vuxna: Utveckling, utnyttjande, utfall. Göteborg: Göteborgs universitet, 1989.

Lundström, Tommy, and Fredrik Wijkström. "Sweden." In Defining the Nonprofit Sector: a Cross-National Analysis, edited by Lester M. Salamon and Helmut K. Anheier, 215-48. Manchester: Manchester University Press, 1997.

Medalis, Christopher. "The Strength of Soft Power: American Cultural Diplomacy and the Fulbright Program during the 1989-1991 Transition Period in Hungary." AUDEM: The International Journal of Higher Education and Democracy 3, no. 1 (2012), 144-63.

Mellander, Erik. "Utbildningsekonomi.” In Individ, samhälle, lärande: Åtta exempel på utbildningsvetenskaplig forskning, edited by Ulf P. Lundgren, 85-97. Stockholm: Vetenskapsrådet, 2008.

Melldahl, Andreas. "Västerled tur och retur del 1: Utbildning och ekonomi. En ekonomhistorisk studie av Sverige-Amerika Stiftelsens stipendieverksamhet 19192006." SEC Research Reports no. 44 Uppsala: Sociology of Education and Culture Research Group, 2008.

Michaëlsson, Madeleine. "From Tree Felling to Silver Lining: Diverse Ways of Funding Elementary Schools among Swedish Ironworking Communities, 18301930." In History of Schooling: Politics and Local Practice, edited by Carla Aubry and Johannes Westberg, 38-67. Frankfurt am Main: Peter Lang, 2012.

Mitch, David. "School Finance." In International Handbook on the Economics of Education, edited by Geraint Johnes and Jill Johnes, 260-97. Cheltenham: Edward Elgar, 2004.

Mitch, David. “The Economic History of Education.” In Routledge Handbook of Modern Economic History, edited by Robert Whaples and Randall E. Parker, 247-64. New York: Routledge, 2013. 
Mitch, David. "The Impact of Subsidies to Elementary Schooling on Enrolment Rates in Nineteenth-Century England." The Economic History Review 39, no. 3 (1986), 371-91.

Morris, Norman. "Public Expenditure on Education in the 1860s." Oxford Review of Education 3, no. 1 (1977), 3-19.

Morris, Norman. The Politics of English Elementary School Finance 1833-1870. Lewiston: Edwin Mellen, 2003.

Mulcahy, Kevin V. "Cultural Diplomacy and the Exchange Programs: 1938-1978." The Journal of Arts Management, Law, and Society 29, no. 1 (1999), 7-28.

Nilsson, Fay Lundh, and Anders Nilsson, eds. Två sidor av samma mynt? Folkbildning och yrkesutbildning vid de nordiska folkhögskolorna. Lund: Nordic Academic Press, 2010.

Nilsson, Sven. Kulturens nya vägar: Kultur, kulturpolitik och kulturutveckling i Sverige. Malmö: Polyvalent, 2003.

Odden, Allan and Larry Picus. School Finance: a Policy Perspective. New York: McGraw-Hill, 1992.

OECD. Education at a Glance: OECD Indicators. Paris: OECD, 2007.

Parmar, Inderjeet. Foundations of the American Century: the Ford, Carnegie, and Rockefeller Foundations in the Rise of American Power. New York: Columbia University Press, 2012.

Petersen, Ann-Louise. Marknadsorientering inom folkbildningen: fritt och frivilligt $i$ ett nytt ljus. Göteborg: Bokförlaget BAS, 2006.

Richmond, Yale. 2003. Cultural Exchange \& the Cold War: Raising the Iron Curtain. University Park, PA: Pennsylvania State University Press.

Rothstein, Bo. Den korporativa staten: Intresseorganisationer och statsförvaltning $i$ svensk politik. Stockholm: Norstedts juridik, 1992.

Rumbley, Laura E., Philip G. Altbach, and Liz Reisberg. "Internationalization Within the Higher Education Context." In The SAGE Handbook of International Higher Education, edited by Darla K. Deardoff, Hans de Wit, John D. Heyl, and Tony Adams, 3-26. London.: SAGE, 2012.

Rupp, Jan C. "The Fulbright Program, or the Surplus Value of Officially Organized Academic Exchange." Journal of Studies in International Education 3, no. 1 (1999), 57-81.

Sandin, Bengt. Hemmet, gatan, fabriken eller skolan: Folkundervisning och barnuppfostran i svenska städer 1600-1850. Lund: Arkiv, 1986.

Schmidt, Oliver. "Small Atlantic World. U.S. Philanthropy and the Expanding International Exchange of Scholars after 1945." In Culture and International History, edited by Jessica C. E. Gienow-Hecht and Frank Schumacher, 115-34. New York: Berghahn, 2004.

Simon, Erica. Réveil national et culture populaire en Scandinavie: La genèse de la højskole nordique 1844-1878. Copenhagen \& Stockholm: Scandinavian University Books, 1960.

Snow, Nancy. "International Exchanges and the U.S. Image." The ANNALS of the American Academy of Political and Social Science 616, no. 1 (2008), 198-222.

Sundgren, Per. Kulturen och arbetarrörelsen: Kulturpolitiska strävanden från August Palm till Tage Erlander. Stockholm: Carlsson, 2007. 
Sundin, Jan. Främmande studenter vid Uppsala universitet före andra världskriget: En studie $i$ studentmigration. Uppsala: Uppsala universitet, 1973.

Swensson, Sven. "Folkhögskolan och myndigheterna." In Svensk folkhögskola 100 år, vol. 1, 135-300. Stockholm: Liber, 1968.

Toepler, Stefan. "Government Funding Policies." In Handbook of Research on Nonprofit Economics and Management, edited by Bruce A. Seaman and Dennis R. Young, 320-34. Cheltenham: Edward Elgar, 2010.

Tøsse, Sigvart. Folkbildning som universellt fenomen: Om betydelser och motsvarigheter $i$ historiskt och internationellt perspektiv. Linköping: Linköpings universitet, 2009.

Tøsse, Sigvart. Folkeopplysning og vaksenopplering: Idear og framvekst gjennom 200 år. Oslo: Didakta Norsk Forlag, 2005.

Tsang, Mun C. “The Economics and Resourcing of Education.” In Routledge International Companion to Education, edited by Bob Moon, Miriam Ben-Peretz, and Sally A. Brown, 128-52. London \& New York: Routledge, 2000.

Wallner, Johan. Folkskolans organisation och förvaltning $i$ Sverige under perioden 1842-1861. Lund: Lunds universitet, 1938.

Welch, Anthony. "Myths and Modes of Mobility: The Changing Face of Academic Mobility in the Global Era." In Students, Staff and Academic Mobility in Higher Education, edited by Mike Byram and Fred Dervin, 292-311. Newcastle: Cambridge Scholars, 2008.

Westberg, Johannes. "Stimulus or Impediment? The Impact of Matching Grants on the Funding of Elementary Schools in Sweden during the Nineteenth Century." History of Education 41, no. 1 (2013), 1-22.

Westberg, Johannes. Att bygga ett skolväsende: Folkskolans förutsättningar och framväxt 1840-1900. Lund: Nordic Academic Press, 2014.

Williams, Gareth. "The Economics of Education: Current Debates and Prospects." British Journal of Educational Studies 30, no. 1 (1982), 97-107.

Windham, D. M. "International Financing of Education." In International Encyclopedia of Economics of Education, edited by Martin Carnoy, 433-38. Oxford: Pergamon, 1995.

Zimmer, Annette, and Stefan Toepler. "The Subsidized Muse: Government and the Arts in Western Europe and the United States." Journal of Cultural Economics 23, no. 1-2 (1999), 33-49. 